\title{
Bacterial suspension feeding by coral reef benthic organisms
}

\author{
R. P. M. Bak ${ }^{1,2, *}$, M. Joenje ${ }^{2}$, I. de Jong ${ }^{1,2}$, D. Y. M. Lambrechts ${ }^{2}$, G. Nieuwland ${ }^{1}$ \\ 'Netherlands Institute for Sea Research (NIOZ), PO Box 59, 1970 AB Den Burg, Texel, The Netherlands \\ ${ }^{2}$ Institute for Systematics and Population Biology, University of Amsterdam, The Netherlands
}

\begin{abstract}
The linkage between the pelagic microbial loop in coral reefs and reef benthic communities needs study in view of changing characteristics of tropical coastal seas. We conducted field experiments, using standard microbial techniques, to assess the uptake of natural water-borne bacteria (at natural densities, 0.4 to $0.6 \times 10^{6} \mathrm{~cm}^{-3}$ ) by 2 common Caribbean reef organisms, the scleractinian coral Madracis mirabilis and the colonial ascidian Trididemnum solidum. The data show that these organisms are effective bacterial suspension feeders. Feeding rates of 0.75 to $1.07 \times 10^{9}$ bacterial cells $100 \mathrm{~cm}^{-2} \mathrm{~h}^{-1}$ translate into a nitrogen input of 3 to $4 \mathrm{nmol}$ $\mathrm{N} \mathrm{cm}^{-2} \mathrm{~h}^{-1}$ These values indicate that a large part of the nitrogen derived from particulate sources could be supplied by bacteria. We suggest that such efficient linkage between these reef organisms and the pelagic microbial communities explains the increasing/continued abundance of such benthic organisms on deteriorating Caribbean reefs
\end{abstract}

KEY WORDS: Coral reef - Pelagic/benthic coupling · Bacteria Suspension feeding $\cdot$ Heterotrophy Ascidia $\cdot$ Nitrogen budget

Vast changes in human demography and distribution are causing changes in seawater quality along tropical coasts, and over increasingly larger areas. Such changes in water quality can have an enormous impact on marine communities. One of many examples is the complete disappearance of once thriving coral reefs (Umbgrove 1939) from the Bay of Jakarta, Indonesia (Tomascik et al. 1997), but it is currently hypothesised that coral reefs are corrupted on a far greater scale, such as caused by the effects of runoff from whole continents (e.g. the ongoing debate on coral-list@coral.aoml.noaa.gov). That characteristics of large bodies of water influence coral reef benthic biota over megascales has been proposed for groups such as sponges. Wilkinson (Wilkinson 1987, Wilkinson \& Chesire 1990) explained variation in the spatial distri-

•E-mail: rbak@nioz.nl bution of reef sponges over areas such as the Great Barrier Reef (Australia) and the Caribbean basin by availability of nutrients and organic matter. Important in such hypotheses is the emphasis on the increase in heterotrophy in affected reefs. Reef sponges are well known for their use of water-borne living particles, such as bacteria (Reiswig 1974, Pile 1997).

Such a trophic relationship between reef organisms and water-borne bacteria, the organisms at the base of the pelagic food web (Fenchel 1987), is highly interesting in view of an increased terrestrial influence in the ocean. The majority of the organic material running into the sea will enter the 'microbial loop' (Azam et al. 1983). There are few data on the linkage of reefs and pelagic bacteria, but recent data show that reef bottoms actively reduce concentrations of bacteria in the adjacent part of the reef water column (Gast et al. 1998). This suggests a possibly important pathway between large-scale oceanic eutrophication and change in reef communities. However, little attention has recently been paid to the trophic relation between non-sponge reef benthos and pelagic bacteria (see Lessios \& Macintyre 1997). The methodology of the pioneering earlier studies (see Sorokin 1993), showing that corals consume pelagic bacteria, is outdated (Ducklow 1990). No data at all are available for Atlantic reefs where, for unknown reasons, significant changes in reef biota are occurring (Ginsburg \& Glynn 1994).

Materials and methods. We present 2 field experiments, using currently standard microbial techniques, to investigate the consumption of reef water column bacteria by 2 benthic reef organisms, Madracis mirabilis (Duchassaing \& Michelotti), a small-branched scleractinian coral, and Trididemnum solidum (van Name), an encrusting colonial ascidian. These are common organisms at the reefs of Curaçao in the southern Caribbean (Bak \& Criens 1981, Bak et al. 1981, 1996b). We used fluorescently labelled bacteria (FLB, Sherr et al. 
1987) in pilot experiments to show that bacteria are taken up by these organisms, e.g. captured in the digestive zones of the mesenteries. We performed our in situ experiments at a depth of 5 to $10 \mathrm{~m}$, enclosing experimental colonies in ambient reef water $\left(27^{\circ} \mathrm{C}\right)$ containing the naturally occurring bacteria. The individual bacteria are small, $<0.2 \mu \mathrm{m}^{3}$, and they occurred at normal densities, 0.4 to $0.6 \times 10^{6} \mathrm{~cm}^{-3}$ (Gast et al. 1998). We measured the change in natural bacterial abundance in experimental and control cylinders. Bacteria were homogeneously distributed and do not sink out (Kiørboe 1993, Karp-Boss et al. 1996).

For each Madracis mirabilis experiment $(n=14)$ we introduced 1 small colony (mean living colony surface $51 \mathrm{~cm}^{2}$ ) underwater into separate, open, $1 \mathrm{l}$ plexiglass cylinders. For each Trididemnum solidum experiment $(\mathrm{n}=8)$ a small encrusting ascidian colony (mean living surface $47 \mathrm{~cm}^{2}$ ) was used. Cylinders filled with ambient seawater without experimental organisms were employed as controls ( $\mathrm{n}=4$ for each series). After closure of the cylinders with $2 \mathrm{O}$-ringed lids at the start of the experiment, each cylinder was sampled $\left(3 \mathrm{~cm}^{3}\right)$ for bacteria through a rubber membrane that gave access to the seawater in the cylinder at $t=0$ and at experimental time intervals (see abscissa of Fig. 1). Bacteria were immediately fixed, in $2 \mathrm{~cm}^{3}$ sterile formaldehyde $(5 \%)$, in the sampling syringe. Samples were stained (Acridine Orange), filtered onto $25 \mathrm{~mm} 0.2 \mu \mathrm{m}$ Sudan Black stained polycarbonate filters (Nuclepore) (Hobbie et al. 1977) and counted using epifluorescence microscopy (Zeiss Axiophot). At least 10 grids (40 $\times$ $40 \mu \mathrm{m}$ ) and 200 cells were counted on each slide (van Duyl et al. 1990, Bak et al. 1995).

Results and discussion. The data show a significant decrease in bacterial densities in the experimental cylinders (Fig. 1), demonstrating that the coral and the

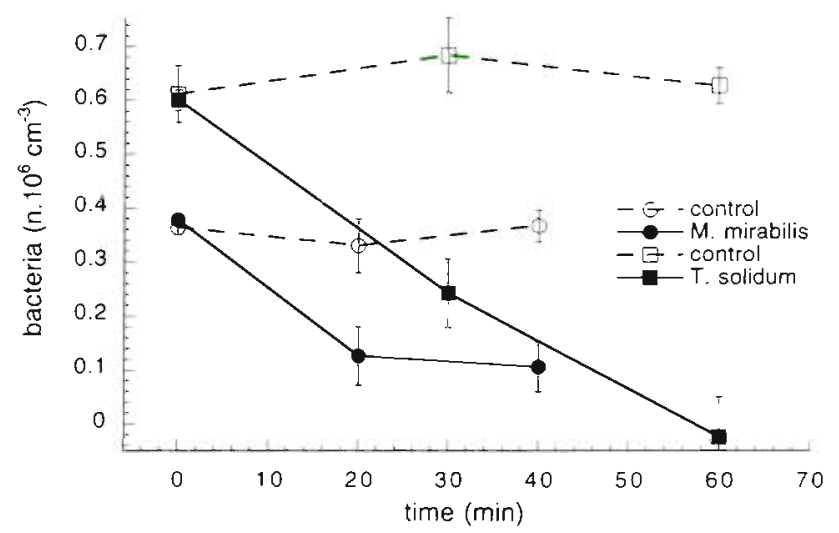

Fig. 1. Madracis mirabilis, Trididemnum solidum. Bacterial suspension feeding of experimental colonies (colony surfaces normalized to $100 \mathrm{~cm}^{2}$ ) in experimental chambers ( $\mathrm{n}=14$ for $M$. mirabilis, $\mathrm{n}=8$ for $T$ solidum) and bacterial density in controls ( $\mathrm{n}=4$ for both). Vertical bars indicate SE ascidian are effective bacterial suspension feeders. Concentrations of bacteria remained constant in control conditions (Fig. 1). Bacterial growth and possible nanoflagellate/ciliate predation are either balanced or insignificant. Gast (1998) found bacterial growth not to result in appreciable changes in cell numbers at this reef over such short time scales and microbial interaction, such as nanoflagellate predation, to be negligible.

Bacterial suspension feeding has been reported for ascidians and corals (Sorokin 1978, Jørgensen et al. 1984, Schlichter 1991, Bak et al. 1996a) but our data do not imply that Madracis mirabilis or Trididemnum solidum actually feed on free-living individual bacteria. The bacteria in our experiments were not manipulated and consequently a large part may have been attached to larger invisible particles, 'hotspots' (Azam 1998), such as colloids and polymer particles. Such larger particles could be the main vehicles facilitating bacterial intake. These particles disintegrate during our sampling procedure but the homogeneous distribution of bacteria in the enclosures indicates a similar distribution of these particles (Wells \& Goldberg 1994).

We do not assume the bacterial uptake rates to represent typical or maximum rates of bacterial suspension feeding of these organisms. However, they show the great potential for coupling of the microbial pelagic to sessile reef organisms. There are a number of considerations. Even though the experimental organisms were allowed to recover from handling (being placed in the cylinders $>20 \mathrm{~h}$ in advance of each experiment) the colonies were slightly disturbed at $t=0$ and the coral polyps, and individual ascidian modules, showed different stages of expansion/relaxation. This is reflected in the variation in feeding rates of the individual colonies (Table 1). None of the organisms was totally expanded. In addition, all experimental organ-

Table 1. Bacterial consumption (no. $\times 10^{3} \mathrm{~h}^{-1}$ ) rates for each colony (surfaces normalised to $100 \mathrm{~cm}^{2}$ )

\begin{tabular}{|ccc|}
\hline Colony & Madracis mirabilis & Trididemnum solidum \\
\hline 1 & 755 & 530 \\
2 & 668 & 807 \\
3 & 713 & 577 \\
4 & 281 & 691 \\
5 & 500 & 701 \\
6 & 8 & 927 \\
7 & 623 & 268 \\
8 & 284 & 481 \\
9 & 25 & - \\
10 & 437 & - \\
11 & 266 & - \\
12 & 132 & - \\
13 & 747 & - \\
14 & 246 & - \\
\hline
\end{tabular}


isms were cleaned for fouling organisms and checked to ensure that no clionid sponges were present. However, the ascidian colonies are encrusting and they disintegrate rapidly if removed from their substratum. Consequently they were used in the experiments while encrusting their natural substratum, thin plates of dead coral rock, and the presence of an occasional clionid sponge in the substratum cannot be ruled out.

There are 2 relevant questions: firstly, are such feeding rates (Fig. 1) of ecological importance and, secondly, is there a relation with changes in the marine environment? The ecological importance would primarily be in terms of nutrient (N, P) uptake. Madracis mirabilis and Trididemnum solidum have endosymbionts and large parts or all of their carbon budget will be supplied by these symbionts (Sybesma et al. 1981, Muscatine 1990). Extrapolating the mean feeding rates measured during the initial 20 min interval (Fig. 1), assuming a carbon content of $20 \mathrm{fg} \mathrm{cell}^{-1}$ (Lee \& Fuhrman 1987) and a C:N:P ratio of 45:10:1 (Zweifel et al. 1993), gives an uptake rate of $2.8 \mathrm{nmol} \mathrm{N} \mathrm{cm}^{-2} \mathrm{~h}^{-1}$ for $M$. mirabilis and $4.0 \mathrm{nmol} \mathrm{cm}^{-2} \mathrm{~h}^{-1}$ for $T$. solidum. These are significant amounts (cf. Bythell 1988, 1990, Szmant 1991). A study using the coral Acropora palmata showed $70 \%$, or $8.75 \mathrm{nmol} \mathrm{N} \mathrm{cm}{ }^{-2} \mathrm{~h}^{-1}$, of the total nitrogen budget to be derived from particulate sources (Bythell 1988). Bacterial suspension feeding at rates such as in our experiments would represent 30 to $45 \%$ of such a particulate feeding pattern and actual uptake rates, for naturally expanded colonies, could be much higher.

It appears that Madracis mirabilis and Trididemnum solidum are linked through suspension feeding to the water column bacteria. Both organisms are very common in Curaçao on the reefs close to, and downcurrent of, human activity and urban development. At least one of them, $T$. solidum, may be positively responding to increased eutrophication. The abundance of $T$ solidum has increased exponentially over the last 15 yr (Bak et al. 1996b). Such an increase is not documented for M. mirabilis. However, although other dominant corals have decreased in cover (e.g. Acropora palmata, Montastraea annularis) over the reefs in Curaçao (Bak \& Nieuwland 1995), M. mirabilis continues to occur in extensive monospecific beds which appear to remain essentially unchanged (van Duyl 1985, Gast unpubl.). Our experimental organisms may represent a group of reef benthos that have a competitive edge in heterotrophy over other reef organisms.

In summary, we use a simple method to demonstrate that there are potentially strong linkages between reef benthos, including corals and ascidians, and water column bacteria. This is possibly an important mechanism coupling reefs, through increased patterns of heterotrophy, to changing conditions of eutrophy in the ocean.
Acknowledgements. We are indebted to the staff of Carmabi for their continuous support and thank Drs John C. Bythell, Gert Jan Gast, Fleur C. van Duyl and Birthe Gade for their comments on the manuscript. This is NIOZ contribution 3338

\section{LITERATURE CITED}

Azam F (1998) Microbial control of oceanic carbon flux: the plot thickens. Science 280:694-696

Azam F, Fenchel T, Field JG, Gray JS, Meyer-Reil LA, Thingstad $F$ (1983) The ecological role of water-column microbes in the sea. Mar Ecol Prog Ser 10:257-263

Bak RPM, Criens SR (1981) Survival after fragmentation of colonies of Madracis mirabilis, Acropora palmata and $A$. cervicornis (Scleractinia) and the subsequent impact of a coral disease. Proc 4th Int Coral Reef Symp 2:221-227

Bak RPM, Nieuwland G (1995) Long-term change in coral communities along depth gradients over leeward reefs in the Netherlands Antilles. Bull Mar Sci 56:609-619

Bak RPM, Sybesma J, Van Duyl FC (1981) The ecology of the tropical compound ascidian Trididemnum solidum. II. Abundance, growth and survival. Mar Ecol Prog Ser 6: $43-52$

Bak RPM, van Duyl FC, Nieuwland G (1995) Organic sedimentation and macrofauna as forcing factors in marine benthic nanoflagellate communities. Microb Ecol 29: $173-182$

Bak RPM, Gast GJ, Joenje M, de Jong I, Lambrechts DYM, Nieuwland G (1996a) The use of fluorescently labelled bacteria (FLB) in studying change in coral reef benthos filter-feeding conditions. Abstracts, 8th Int Coral Reef Symp. Smithonian Tropical Research Institute, Balboa, Panama, p 11

Bak RPM, Lambrechts DYM, Joenje M, Nieuwland G, Van Veghel MLJ (1996b) Long-term changes on coral reefs in booming populations of a competitive colonial ascidian. Mar Ecol Prog Ser 133:303-306

Bythell JC (1988) A total nitrogen and carbon budget for the elkhorn coral Acropora palmata (Lamarck). Proc 6th Int Coral Reef Symp 2:535-540

Bythell JC (1990) Nutrient uptake in the reef-building coral Acropora palmata at natural environmental concentrations. Mar Ecol Prog Ser 68:1-2

Ducklow HW (1990) The biomass, production and fate of bacteria in coral reefs. In: Dubinsky $Z$ (ed) Coral reefs. Elsevier, Amsterdam, p 265-290

Fenchel T (1987) Ecology-potentials and limitations. In: Kinne $O$ (ed) Excellence in ecology, Book 1. Ecology Institute, Oldendorf/Luhe

Gast GJ (1998) Microbial densities and dynamics in fringing coral reef waters. PhD thesis, University of Amsterdam

Gast GJ, Wiegman S, Wieringa E, van Duyl FC, Bak RPM (1998) Bacteria in coral reef water types: removal of cells, stimulation of growth and mineralization. Mar Ecol Prog Ser 167:37-45

Ginsburg RN, Glynn PW (1994) Summary of the colloquim and forum on global aspects of coral reefs: health, hazards and history. In: Ginsburg RN (ed) Proc Colloquium Global Aspects Coral Reefs. RSMAS, University of Miami, Miami, $\mathrm{pi}-\mathrm{ix}$

Hobbie JE, Daley RJ, Jasper S (1977) Use of nuclepore filters for counting bacteria by fluorescence microscopy. Appl Environ Microbiol 33:1225-1228

Jørgensen CB, Kiørboe T, Møhlenberg F, Riisgård HU (1984) Ciliary and mucus-net filter feeding, with special reference to fluid mechanical characteristics. Mar Ecol Prog Ser 
$15: 283-292$

Karp-Boss L, Boss E, Jumars PA (1996) Nutrient fluxes to planktonic osmotrophs in the presence of fluid motion. Oceanogr Mar Biol Annu Rev 43:71-107

Kiørboe T (1993) Turbulence, phytoplankton cell size, and the structure of pelagic food webs. Adv Mar Biol 29:1-72

Lee S, Fuhrman JA (1987) Relationships between biovolume and biomass of naturally derived marine bacterioplankton. Appl Environ Microbiol 53:1298-1303

Lessios HA, Macintyre IG (eds) (1997) Proceedings of the 8th International Coral Reef Symposium. Smithonian Tropical Research Institute, Balboa, Panama

Muscatine $L$ (1990) The role of symbiotic algae in carbon and energy flux in reef corals. In: Dubinsky $Z$ (ed) Coral reefs. Elsevier, Amsterdam, p 75-88

Pile AJ (1997) Finding Reiswig's missing carbon: quantification of sponge feeding using dual-beam flow cytometry. Proc 8th Int Coral Reef Symp 2:1403-1410

Reiswig HM (1974) Water transport, respiration and energetics of three tropical marine sponges. J Exp Mar Biol Ecol 14:231-249

Schlichter D (1991) A perforated gastrovascular cavity in the symbiotic deep-water coral Leptoseris fragilis: a new strategy to optimize heterotrophic nutrition. Helgol Meeresunters 45:423-443

Sherr BF, Sherr EB, Fallon RD (1987) Use of monodispersed, fluorescently labelled bacteria to estimate in situ protozoan bacterivory. Appl Environ Microbiol 53:958-965

Sorokin YI (1978) Microbial production in the coral reef community. Arch Hydrobiol 83:281-323

Sorokin YI (1993) Coral reef ecology. Springer, Berlin

Editorial responsibility: Otto Kinne (Editor),

Oldendorf/Luhe, Germany
Sybesma J, van Duyl FC, Bak RPM (1981) The ecology of the tropical compound ascidian Trididemnum solidum. III. Symbiotic association with unicellular algae. Mar Ecol Prog Ser 6:53-59

Szmant AM (1991) Sexual reproduction by the Caribbean reef corals Montastrea annularis and $M$. cavernosa. Mar Ecol Prog Ser 74:13-25

Tomascik T, Mah AJ, Nontji A, Moosa MK (1997) The ecology of the Indonesian seas. Periplus, Sydney

Umbgrove JHF (1939) Madreporaria from the Bay of Batavia. Zool Meded 22:1-64

van Duyl FC (1985) Atlas of the living reefs of Curaçao and Bonaire (Netherlands Antilles). Found Scient Res Surinam, Netherlands Antilles

van Duyl FC, Bak RPM, Kop AJ, Nieuwland G (1990) Bacteria, auto- and heterotrophic nanoflagellates, and their relations in mixed, frontal and stratified waters of the North Sea. Neth J Sea Res 26:97-109

Wells ML, Goldberg ED (1994) The distribution of colloids in the North Atlantic and Southern Oceans. Limnol Oceanogr 39:286-302

Wilkinson CR (1987) Interocean differences in size and nutrition of coral reef sponge populations. Science 236: $1654-1657$

Wilkinson CR, Cheshire C (1990) Comparisons of sponge populations across the Barrier Reefs of Australia and Belize: evidence for higher productivity in the Caribbean. Mar Ecol Prog Ser 67:285-294

Zweifel UL, Norrman B, Hagström $\AA$ (1993) Consumption of dissolved organic carbon by marine bacteria and demand for inorganic nutrients. Mar Ecol Prog Ser 101:23-32

Submitted: August 6, 1998; Accepted: November 18, 1998 Proofs received from author(s): December 10, 1998 